\title{
Ortaokul Matematik Öğretmen Adaylarının Dağılım Kavramına İlişkin Anlamalarının İncelenmesi
}

\author{
An Investigation of Pre-service Middle School Mathematics Teachers' \\ Understanding of Distribution \\ Nadide YILMAZ* \\ • Geliş Tarihi: 22.04.2019 • Kabul Tarihi: 07.01.2020 • Çevrimiçi Yayın Tarihi: 24.02.2020
}

\section{$\ddot{O} \mathbf{z}$}

$\mathrm{Bu}$ çalışmada ortaokul matematik öğretmen adaylarının dağılım ve bununla ilişkili kavramlara ilişkin anlamalarını ortaya çıkarmak amaçlanmıştır. Bu amaçla nitel araştırma desenlerinden fenomenografik araştırma yöntemi kullanılmış ve 66 üçüncü sınıf öğretmen adayı ile çalışılmıştır. Lee ve Meletiou-Mavrotheris (2003) çalışmasından yararlanılarak hazırlanan etkinlikler yardımıyla öğretmen adaylarıyla görüşmeler gerçekleştirilmiştir. Elde edilen veriler ölçülmek istenen bilgi ve beceriler kapsamında analiz edilmiştir. Bulgular öğretmen adaylarının bağlama uygun histogramın eksenlerini isimlendirebilmede, dağılım grafiği oluşturabilmeye göre daha başarılı olduklarını ortaya çıkarmıştır. Dağılım grafiğinden yola çıkarak gerçek yaşam durumlarını değerlendirememişlerdir. Verilen dağılımın grafiksel gösterimi ile değişkenlik arasında bağlantı kurmakta zorlanmışlardır. Farklı bağlamlar üzerinde çalışmaları istendiğinde ise öğretmen adaylarının doğru cevaplara bile yanlış akıl yürütmelerle ulaştıkları gözlenmiştir. Burada hareketle öğretmen adaylarının dağılım ve bu kavramla ilişkili kavramlar arasındaki ilişkileri fark etmelerine yönelik etkinliklerle meşgul olmaları ve bu kavramlar üzerine tartışmaları önerisi dile getirilmiştir.

Anahtar sözcükler: dağılım, değişkenlik, histogram, öğretmen adayları, alan bilgisi.

Atıf:

Yılmaz, N. (2020). Ortaokul matematik öğretmen adaylarının dağılım kavramına ilişkin anlamalarının incelenmesi. Pamukkale Üniversitesi Eğitim Fakültesi Dergisi, 50, 374-398. doi:10.9779/pauefd.556836

\footnotetext{
* Dr., Araş. Gör., Karamanoğlu Mehmetbey Üniversitesi, Karaman- Türkiye, ORCID: https://orcid.org/0000-00031624-5902, nadideylmz70@gmail.com
} 
Ortaokul Matematik Öğretmen Adaylarının Dağılım Kavramına İlişkin Anlamalarının İncelenmesi 375

\begin{abstract}
In this study, it was aimed to reveal pre-service middle school mathematics teachers' understandings about the concept of distribution and related concepts. It was adopted, the phenomenographic research method, one of the qualitative research designs, was employed on 66 third-year pre-service teachers. Through the activities developed on the basis of the study conducted by Lee and Meletiou-Mavrotheris (2003), interviews were conducted. The collected data were analyzed within the context of the knowledge and skills intended to be measured. The findings have revealed that the pre-service teachers were more successful in naming histogram axes complying with the context than constructing distribution graphs. They were not able to evaluate real life situations on the basis of the distribution. They had difficulties in establishing connections between the given graphical display of distribution and variation. When they were asked to work on different contexts, it was observed that the pre-service teachers even arrived at correct answers through incorrect reasoning. Thus, it was suggested that pre-service teachers should be engaged in activities helping them recognize the relationships between the concept of distribution and related concepts and should discuss about these concepts.
\end{abstract}

Keywords: distribution, variation, histogram, pre-service teachers, content knowledge

Cited:

Y1lmaz, N. (2020). An investigation pf pre-service middle school mathematics teachers' understanding of distribution. Pamukkale Üniversitesi Ĕgitim Fakültesi Dergisi, 50, 374-398.doi:10.9779/pauefd. 556836 


\section{Giriş}

Günlük yaşamda veriye dayalı kararlar almaya olan ihtiyacın artması istatistiğin daha da önemli hale gelmesine neden olmuş, bireylerin bu ihtiyaçlara ilişkin bilgi ve becerilerinin geliştirilmesi gereğini doğurmuştur (Vermette \& Savard, 2019). İstatistiksel bir araştırma yaparken nihai amaçlardan biri de bağlam içerisinde yer alan gerçekliğin ne anlama geldiğini anlamak ve anlamlandırmaktır (Wild, 2006). Bu sürecin doğru yürütülebilmesi için akıl yürütme ve düşünme becerileri önemli rol oynar. İstatistiksel düşünme ve akıl yürütmeye sahip bireylerin kavramların ne anlama geldiğini işlemsel ve kavramsal olarak değerlendirebilmelerinin yanında verinin nasıl ele alınması gerektiğine ilişkin bilgi ve becerilere sahip oldukları ifade edilmektedir (Garfield, 2003; Garfield \& Chance, 2000; Moore, 1990; Pfannkuch \&Wild, 2004; Wild, 2006; Wild \& Pfannkuch, 1999). Grafiksel temsillerin yanında dağılım ve değişkenlik kavramları istatistiksel düşünme ve akıl yürütme süreçlerinin temelini oluşturur (Bakker, 2004; Bakker \& Gravemeijer, 2004; Ben-Zvi, 2004; Reading \& Reid, 2006; Reading \& Shaughnessy, 2004; Wild, 2006; Wild \& Pfannkuch, 1999). Bu kavramların ne anlama geldiği ve istatistiksel araştırmada nasıl bir rol üstlendiğine ilişkin farkındalık verilerin nasıl dağıldığ 1 ve bu dağılımın ne anlama geldiğine ilişkin doğru yorumlamalar yapabilmeye de imkan verir (Konold \& Pollatsek, 2002; Scheaffer, 2006; Wild, 2006). Aynı zamanda bu kavramların birbirleriyle olan ilişkisi istatistiksel bilgi ağının anlamlandırılması için kritik öneme sahiptir (Reading \& Canada, 2011). Dağılım da bu bilgi ağında yer alan kavramlardan biridir (Reading \& Canada, 2011; Shaughnessy, 2007). Bu kavramın tanımı görece basit olmasına rağmen (Reading \& Canada, 2011) anlaşılması zor bir kavram olarak nitelendirilmektedir (Pfannkuch \& Reading, 2006; Shaughnessy, 2007). Bu kavram merkez, yayılım, değişkenlik gibi birçok kavramı aynı anda kullanmay1 gerektirir (Bakker \& Gravemeijer, 2004; Reading \& Canada, 2011; Reading \& Reid, 2006; Sanchez, Silva \& Coutinho, 2011). Dağılım kavramını ele almanın bir diğer yolu da verilerdeki önemli noktaların ve eğilimlerin belirlemesidir. Bu sayede dağılım hakkında bilgi edinilir ve anlamlandırılır (Friel, Mokros \& Russell, 1992). Bu noktada grafiksel temsiller kilit rol oynar ve sadece merkezi eğilim ölçüleri değerlerine göre karar vermeyi engeller. Ayrıca bu temsiller verinin tamamını görmeye imkan verdiği için verinin bütünü hakkında yorum yapmaya olanak sağlar (Leavy, 2006; Tufte, 1983). Verinin bütünü hakkında değerlendirme yapabilmek "istatistiksel perspektif" bakış açısını gerektirir ve farklı dağılımları kıyaslarken de bu geçerlidir (Makar \& Confrey, 2004). Aynı zamanda bir dağılımın grafiği değiş̧kenin değişimi hakkında bilgi sunar (Garfield \& Ben-Zvi, 2008c).

Geleneksel istatistik sınıflarında öğretim sürecinde grafiklerin oluşturulmasına odaklanılır ve bireyler çoğunlukla bu grafiklerin neden oluşturulması gerektiği konusunu anlamlandırmakta zorlanır (Friel, Curcio \& Bright, 2001). Grafiklerin verileri temsil etmeye imkan vermesinin yanında, bu verileri bütüncül bir şekilde değerlendirmeye olanak sağladığı söylenebilir. Ayrıca diğer istatistiksel kavramlarla ilişkilendirerek anlam çıartmaya yardım eden akıl yürütme araçları olarak kullanılabilir (Wild \& Pfannkuch, 1999; Konold \& Pollatsek, 2002).Bu noktada devreye giren bir diğer önemli istatistiksel kavram ise değişkenlik kavramıdır. Değişkenlik, dağılımın anlamlandırılmasında kilit rol oynar (Bakker, 2004; Leavy, 2006; Pfannkuch \& Reading, 2006; Shaughnessy, 2007; Garfield \& Ben-Zvi, 2008a). Hatta baz1 araştırmacılar istatistiksel düşünmede değişkenlik kavramını istatistiğin olmazsa olmazı olarak nitelendirmişlerdir. (Pfannkuch \& Wild, 2004; Reading \& Shaughnessy, 2004; Sánchez ve 
diğerleri, 2011). Buna ek olarak araştırmacılar dağılım ve değişkenlik kavramı arasındaki bağlantının önemine değinmişlerdir (Bakker, 2004; Ben-Zvi, 2004; Groth \& MeletiouMavrotheris, 2018; Makar \& Confrey, 2003). Dağılım kavramını "verinin değişkenliğinin görsel sunumu" (Makar \& Confrey, 2005) olarak nitelemişler, aralarındaki ilişkiyi "değişim olmazsa dağılım olmaz" şeklinde ifade etmişlerdir (Bakker \& Gravemeijer, 2004).

İstatistik kavramları ve bu kavramlar arasındaki ilişkilere öğretim programlarında da yer verilmesi ve öğrenme sürecinde bu kavramlara vurgu yapılmasının önemine dikkat çekilmektedir (Moore, 1990). Hazırlanan uluslararası raporlarda da benzer vurguya yer verildiği söylenebilir (Franklin, Bargagliotti, Case, Kader, Scheaffer \& Spangler, 2015; Franklin, Kader, Mewborn, Moreno, Peck, Perry \& Scheaffer, 2005). Türkiye'deki öğretim programlarında da bu vurguya bazen açık bazen de örtük bir şekilde yer verildiği ifade edilmektedir (Milli Eğitim Bakanlığı [MEB], 2009, 2013, 2018). Öğretim programlarında istatistik kavramlarına yapılan vurgu programların uygulayıcıları olan öğretmenlerin bu konuda gerekli bilgi ve becerilere sahip olmalarını gerekli kılmaktadır (Ball, Thames \& Phelps, 2008; Groth, 2007; National Council of Teachers of Mathematics [NCTM], 2000; Shulman, 1986). Watson (2005) gerçekleştirdiği çalışmasında küçük yaş grubunda yer alan öğrencilerin resim grafiği üzerinde çalışmaya başlamalarıyla birlikte aslında dağılım kavramını fark ettiklerini ifade etmiştir. Öğrencilerde bu farkındalığın oluşması öğretmenin sahip olduğu bilgiyle doğrudan ilişkilidir (Ball \& McDiarmid, 1990; Ball ve diğerleri, 2008). Araştırmalar zayıf alan bilgisine sahip olmanın prosedürsel işlemlere ve kurallara aşırı bağllığa sebep olabileceğini göstermektedir (Stein, Baxter \& Leinhardt, 1990). Ayrıca yapılan araştırmalar öğretmenlerin bu bilgi eksikliklerinin öğretim sürecinde uygun temsilleri seçmelerini ve yapacağı açıklamaları sınırlayacağını göstermektedir (Borko, Eisenhart, Brown, Underhill, Jones \& Agard, 1992). Alan bilgisi ile öğretim bilgisi arasındaki bu ilişki öğretmen adaylarının istatistiksel kavramlara ilişkin anlamaları ve öğretecekleri konunun daha fazlasını bilmelerini kritik hale getirmektedir (Borko ve diğerleri, 1992; Leavy, 2006). Ancak yapılan çalışmalar öğretmenlerin ve öğretmen adaylarının dağılım kavramı ve bu kavramın ilişkili olduğu diğer kavramların anlaşılması konusunda çeşitli zorluklarının olduğunu göstermektedir (Bakker \& Gravemeijer, 2004; Cooper \& Shore 2010; Garfield \& Ben-Zvi, 2008a; Shaughnessy, 2007).

Merkezi eğilim ölçülerine odaklanan çalışmaların bazılarında öğretmen ve öğretmen adaylarının ortalama kavramını nasıl algıladıkları incelenirken (Leavy \& O'Loughlin, 2006), bazı çalışmalarda aritmetik ortalama, mod ve medyan kavramlarına odaklanıldığı gözlenmiştir (Groth \& Bergner, 2006; f, 2012). Ortaya çıkan en çarpıcı sonuç öğretmen ve öğretmen adaylarının bu kavramlara ilişkin bilgilerinde kavramsal eksiklikler olduğudur (Leavy, 2006; Leavy \& O'Loughlin, 2006; Sorto, 2004). Örneğin Leavy ve O’Loughlin (2006) gerçekleştirdikleri çalışmada öğretmen adaylarının aritmetik ortalama kavramının nasıl hesaplanacağına ilişkin bilgiye sahip olmalarına rağmen bu kavramın ne gibi anlamlarının olduğunu değerlendiremediklerini gözlemiş, ağırlıklı ortalama kavramına ilişkin problemleri çözmekte zorlandıklarını ortaya çıkarmıştır. Buna ek olarak öğretmenler aritmetik ortalamayı hesaplayabilmesine rağmen grupları karşılaştırmakta zorlanmışlardır (Canada, 2004; Leavy \& O’Loughlin, 2006; Makar, 2004; Makar \& Confrey, 2004). Yani başka bir deyişle katılımcıların aritmetik ortalama kavramına ilişkin işlemsel bilgiye sahip oldukları ancak kavramsal bilgilerinde eksiklikler olduğu söylenebilir. Bu noktada öğrencilerin geleceğini şekillendirmede kilit rol oynayan öğretmenlerin kavramların ne anlama geldiği üzerine de gerekli bilgi ve 
becerilere sahip olmalarının alan bilgilerinin niteliğini belirleyen önemli bir değişken olduğu yorumu yapılabilir (Hiebert \& Lefevre, 1986; NCTM, 2000). Ayrıca öğretmenlerin merkezi eğilim ölçüleri ile yayılım ölçüleri arasındaki bağlantıyı anlamlandırmakta zorlandıkları gözlenmiştir (Lee \& Lee, 2011). İstatistiksel ölçümleri algoritmalarla sınırlı gördükleri için dağılımın merkezi ve değişkenliğini çeşitli kavram yanılgıları ve yanlış akıl yürütmelerle değerlendirmişlerdir (Cooper \& Shore 2010; delMas \& Liu 2005; Lee \& Meletiou-Mavrothesis, 2003; Mickelson \& Heaton, 2004; Reading \& Shaugnessy, 2004; Garfield \& Ben-Zvi, 2008b). Ayrıca bu zorlukların öğrencilerin yaşadıkları zorluklarla benzerlik gösterdiği belirlenmiştir (Groth \& Meletiou-Mavrotheris, 2018; Shaughnessy, 2007). Örneğin histogramların değişkenliğini incelerken yatay eksenler yerine dikey eksenlere bakarak değişkenliği karşılaştırma eğiliminde olmuşlar doğru cevaplarını yanlış gerekçelerle açıklamışlardır (Lee \& Meletiou-Mavrothesis, 2003). Bazı durumlarda grafiksel temsillerden yola çıkarak tayin edilen değişkenlik ölçüleri ile yapılmış ölçümlerden elde edilenler arasında bağlantı kurmakta zorlanmışlardır (Cooper \& Shore 2010). Birçok öğretmenin veri dağılımının bütününe bakmak yerine dağılımın merkezine ya da açıklık veya belli değerlere odaklandıkları gözlenmiştir (Groth \& Meletiou-Mavrotheris, 2018; Makar \& Confrey, 2005). Mickelson ve Heaton (2004) bir üçüncü sınıf öğretmeninin dağılıma ilişkin akıl yürütmesini incelediği çalışmasında bağlam değiştikçe öğretmenin dağılım hakkında akıl yürütmekte zorlandığını ve tutarsız düşünceler ürettiğini ortaya çıkarmıştır.

Yayılım ölçülerine ilişkin çalışmaların bazılarında değişkenlik kavramının anlamına odaklanılmışken (Cooper \& Shore, 2008; Garfield, delMas \& Chance, 2007; Meletiou \& Lee, 2002), bazılarında ise dağılım ve histogram kavramlarından hareketle verilerin değişkenliği ele alınmıştır (Chaphalkar \& Leary, 2014). İstatistik kursunu başarıyla tanımlayan bireylerin bile değişkenliği anlamakta zorlandıklarını gözlenmiştir (Garfield ve diğerleri, 2007). Ayrıca simetrik dağılıma sahip olan verilerin düşük değişkenliğe sahip olduğu gibi bir yanılgıya da sahip oldukları ortaya çıkmıştır (delMas \& Liu 2005). Kuntze (2014), bazı ortaöğretim öğretmenlerinin değişkenliği öğretmeyi önemli bir öğretim hedefi olarak görmediklerini ifade etmiştir. Bunun yanında öğretmen/öğretmen adayları standart sapmanın nasıl hesaplanacağ konusunda bilgi sahibi olmalarına rağmen bu kavramın nasıl yorumlanması gerektiği ve verilerdeki değişkenlikle nasıl ilişkilendirileceği hakkında yeterli bilgiye sahip değildir (Leavy, 2006; Garfield \& Ben-Zvi, 2008b; Makar \& Confrey, 2005; Mathews \& Clark 2003; Sorto, 2004). Çok az sayıda katılımcının ortalamanın yerini tayin ederken ortalamadan sapmaları ve bu sapmaların merkez için ne anlama geldiğini dikkate alabildiklerini gözlemiştir. Farklı dağılımları kıyaslarken de benzer zorluklar gözlenmiştir (Watson \& Moritz, 1999; Makar \& Confrey, 2005).

Öğretmen ve öğretmen adaylarının yaşadıkları bu zorluklar dağılım, değişkenlik, standart sapma, merkez gibi önemli istatistik kavramlarının açık bir şekilde birbiriyle bağlantılı olduğunu göstermektedir. Bir kavramda var olan eksiklik diğer kavramın gelişimine de olumsuz yönde etkilemektedir (Bakker, 2004; Leavy, 2006; Garfield \& Ben-Zvi, 2008a; Pfannkuch \& Reading, 2006; Reading \& Reid, 2006; Shaughnessy, 2007). Garfield ve Ben-Zvi (2005) grafiklerin görünümünün diğer istatistik kavramların anlamlandırılabilmesi için bir engel olabileceğini ifade etmiş değişkenlik kavramının farklı grafiklerde, özellikle histogramlarda nasıl ortaya çıktığını tanıyıp anlayabilmenin önemine vurgu yapmıştır. Ancak bu durum öğrenim sürecinde çokta dikkate alınmamaktadır. Ayrıca grafiksel temsillerle ifade edilen 
dağılımın anlamlandırılması konusunda grafiklerin nasıl bir işlev üstlendiği konusunda çok az şey bilinmektedir (Leavy, 2006). Daha çok grafiklerin oluşturulmasına odaklanıldığı için değerler (maksimum, minimum, uç değerler...) ile dağılımın merkezi ve merkezin etrafında yayılan verilerin nasıl ilişkili olduğuna yeterince değinilmemektedir (Cooper \& Shore 2008). Etkili bir istatistik öğretimi için öğretmenin bilgisinin kilit noktada olduğu düşünülürse bu kavramlara ilişkin bilgi sahibi olmasının öğrenme-öğretme sürecini doğrudan etkileyeceği söylenebilir (Mickelson \& Heaton, 2004; Reading \& Canada, 2011; Vermette \& Savard, 2019). Bu bağlamda öğretmen adaylarının bu kavramlara ilişkin bilgilerinin ortaya çıkarılmasının buna ilişkin derslerin yapılandırılması sürecinde önemli ipuçları sunabileceği düşünülmektedir. Buradan yola çıkarak bu araştırmada öğretmen adaylarının dağılım ve bununla ilişkili kavramları (değişkenlik, histogram) nasıl algıladığı ve anlamlandırdığını ortaya çıkarmak amaçlanmış ve aşağıdaki problem ve alt problemlere cevap aranmıştır.

1.Öğretmen adayları dağılım ve bununla ilişkili kavramları (değişkenlik, histogram) nasıl algılamakta ve anlamlandırmaktadır?

1.a.Öğretmen adayları bağlama uygun histogramın eksenlerini isimlendirebilmeye ilişkin hangi bilgi ve becerilere sahiptir?

1.b.Öğretmen adayları bağlama uygun dağılım grafiği oluşturabilmeye ilişkin hangi bilgi ve becerilere sahiptir?

1.c.Öğretmen adayları verilen dağılım grafiğinden yola çıkarak gerçek yaşam durumlarını nasıl değerlendirmektedir?

1.d.Öğretmen adayları dağılımın grafiksel gösterimi ile değişkenlik arasında nasıl bağlantılar kurmaktadır?

\section{Yöntem}

\section{Araştırmanın Deseni}

$\mathrm{Bu}$ çalışmada nitel araştırma desenlerinden fenomenografik araştırma yöntemi kullanılmıştır. $\mathrm{Bu}$ yöntem bireyin ilgili fenomen veya kavramı nasıl algıladığı veya anlamlandırdığını keşfetmeye imkan verir (Cresswell, 2013; Marton, 1988). Bu sayede kişinin ilgili kavramı nasıl gördüğü tasvir edilir yani betimlenir (Asworth \& Lucas, 1998). Çünkü aynı kavram veya olguyu bile bireyler farklı algılayabilir. Fenomenografik yöntem sayesinde bireylerin bu farklı algılayışları ortaya çıkarılır (Trigwell, 2006). Bu çalışmada da öğretmen adaylarının dağılım ve bununla ilişki kavramları nasıl algıladığı ve anlamlandırdığını ortaya koymak amaçlandığı için fenomenografik araştırma yöntemi benimsenmiştir.

\section{Çalışma Grubu}

Çalışmaya 2017-2018 eğitim öğretim yılı güz döneminde Ankara'da bir devlet üniversitesinde öğrenim gören 66 üçüncü sınıf matematik öğretmen adayı katılmıştır. Bu öğretmen adaylarından 13’ü erkek, 53 kadındır. Katılımcılar ölçüt örnekleme yöntemiyle belirlenmiştir. Bu sayede belirlenen ölçütleri taşıyan durumlara odaklanılarak odaklanılan durumlar ayrıntılı incelenebilir (Gall, Gall \& Borg, 2007). Bu çalışmada da katılımcılar belirlenirken zorunlu bir ders olan İstatistik ve Olasılık-1 dersini almış olmaları ölçüt olarak belirlenmiştir. Öğretmen adayları bu dersi 3. sınıfın birinci dönemi yani beşinci yarıyılda almışlardır. Öğretmen adaylarıyla 
gerçekleştirilen görüşmeler bu dersin öğretim sürecinin bitimi olan beşinci yarıyılın sonunda yapılmıştır. Öğretmen adaylarının bu derse ilişkin başarı durumları Tablo 1'de ifade edilmiştir.

Tablo 1. Çalışmaya Katılan Öğretmen Adaylarının Başarı Durumları

\begin{tabular}{lll}
\hline Öğrenci seviyesi (100 puan üzerinden) & Öğrenci sayıs1 & Yüzde (\%) \\
\hline $85-100$ & 34 & 52 \\
$70-84$ & 30 & 45 \\
$55-69$ & 2 & 3 \\
\hline
\end{tabular}

Tablodan da görüldüğü gibi araştırmaya katılan öğretmen adaylarının \%52'si 85-100, \%45'i 70-84, \%3'ü ise 55-69 puan aralığındadır. Öğretmen adaylarının genel olarak başarılı olduğu söylenebilir. Öğretmen adaylarının isimleri saklı tutulmuş, Ö1,Ö2,... şeklinde kodlanmıştır.

\section{Veri Toplama Aracı ve Veri Toplama Süreci}

Öğretmen adaylarının dağılım ve bu kavramla ilişkili kavramları nasıl anladıkları ve anlamlandırdıklarını ortaya çıkarmak için etkinlikler içeren görüşme formu kullanılmıştır. Görüşme formu oluşturulurken Lee ve Meletiou-Mavrotheris (2003) çalışmasından yararlanılmıştır. Burada yer alan etkinlikler Türkçe'ye çevrilmiştir. Görüşme formundaki sorular ve ölçülmesi hedeflenen bilgi ve beceriler Tablo 2'de gösterilmiştir. Görüşme formundaki sorular Ek 1'de verilmiştir.

Tablo 2. Görüşme formundaki Sorular ile Ölçülmesi Hedeflenen Bilgi ve Beceriler

\begin{tabular}{ll}
\hline Ölçülen bilgi ve beceriler & Soru numarası \\
\hline Verilen bağlama uygun histogramın eksenlerini isimlendirebilme & $1 \mathrm{~b}, 4 \mathrm{a}$ \\
Verilen bağlama uygun dağılım grafiği oluşturabilme & $1 \mathrm{a}, 4 \mathrm{~b}$ \\
Dağğlım grafiğinden yola çıkarak geç̧ek yasam durumlarını değerlendirebilme & $1 \mathrm{c}$ \\
Dağılımın grafiksel gösterimi ile değişkenlik arasındaki bağlantıyı kurabilme & $2,3 \mathrm{a}, 3 \mathrm{~b}$ \\
\hline
\end{tabular}

Görüşme formundaki birinci etkinliğin $b$ şıkkı ile dördüncü etkinliğin a şıkkı öğretmen adaylarının verilen bağlama uygun histogramın eksenlerini isimlendirebilmeye ilişkin bilgi ve becerilerini ortaya çıkarmayı amaçlamıştır. Bu iki soru yapı olarak aynı olmakla birlikte farklı bağlamlar içermektedir. Birinci etkinliğin a şıkkı ile dördüncü etkinliğin $\mathrm{b}$ şıkkında da benzer durum gözlenmiştir. $\mathrm{Bu}$ sorularla da öğretmen adaylarının verilen bağlama uygun dağılım grafiği oluşturabilmeye ilişkin bilgi ve becerileri incelenmiştir. Birinci etkinliğin $\mathrm{c}$ şıkkı ise dağılım grafiğinden yola çıkarak gerçek yaşam durumlarını değerlendirebilmeyi hedeflemiştir. Öğretmen adaylarının dağılımın grafiksel gösterimi ile değişkenlik arasındaki bağlantıyı kurabilmeye ilişkin bilgi ve becerileri ise ikinci ve üçüncü etkinlikler yoluyla değerlendirilmiştir. Hazırlanan görüşme formundaki etkinliklerin ölçülmek istenen bilgi ve becerilere uygun olup olmadığı ve anlaş1lırlığ için üç alan uzmanının görüşlerine başvurulmuş ve bu sayede ölçme aracının iç geçerliği sağlanmaya çalışılmıştır. Uzmanlar etkinliklerin ölçülmek istenen bilgi ve becerileri ölçtüğü konusunda fikir birliğine varmışlar ancak ifadelerde bazı düzenlemelere gidilmesi gerektiğini ifade etmişlerdir. Bu noktadan hareketle etkinlik 2'de A ve $B$ bitkisi olarak ifade edilen dağılım isimleri çam ağacı ve meşe ağacı şeklinde değiştirilmiştir. Bunun yanında etkinlik 4'de yer alan "ücretin dağılımının şekli neye benziyor?" sorusu "maaş dağılımının şekli neye benziyor?" şeklinde değiştirilmiştir. Ayrıca etkinlik 3'ün c şıkkında yer alan "çünkü bu dağılım daha fazla farklı puan içerir." ifadesi "çünkü bu dağılım daha fazla sayıda farklı puanlar içerir." şeklinde düzenlenmiştir. Gerekli düzenlemelerden sonra 
soruların açık ve anlaşılır olup olmadığı, verilen cevapların soruları yansıtma düzeylerini incelenmek amacıyla da pilot çalışma yapılmıştır. Pilot çalışma 5 öğretmen adayı ile gerçekleştirilmiştir. Bu çalışmadan sonra bazı düzenlemelere ihtiyaç olduğu fark edilmiştir. Öğretmen adaylarından sorulara ilişkin cevaplarını gerekçelendirmeleri istenmesine rağmen bunu göz ardı ettikleri gözlenmiştir. Bu yüzden asıl çalışma sırasında araştırmacı öğretmen adaylarından cevaplarını gerekçelendirmeleri gerektiğine ayrıca vurgu yapmış ve nasıl düşündüklerini ortaya çıkaracak "Nasıl düşündün?, neden böyle yaptın?" şeklinde sorular sormuştur. Görüşmeler yaklaşık olarak 40-50 dakika aralığında gerçekleştirilmiştir.

\section{Veri Analizi}

Çalışmada veriler betimsel analiz yöntemiyle analiz edilmiştir. Bu sayede elde edilen veriler oluşturulan kodlar yardımıyla analiz edilerek ne anlam ifade ettiği ortaya konur (Merriam, 2009). Öğretmen adaylarının cevapları ölçülmesi hedeflenen bilgi ve beceriler çerçevesinde kodlanmış ve bu çerçevede değerlendirilmiştir. Öğretmen adaylarının cevapları öncelikle doğru ve yanlış şeklinde gruplandırılırken sonrasında bu cevapların gerekçelerine ilişkin örnekler okuyucuya sunulmuştur. Doğru ve yanlış cevapların nedenleri de ortaya konmuş, bulgular bu çerçevede yorumlanmıştır.

Nitel araştırmaların geçerli ve güvenilir olabilmesi bazı ölçütleri sağlamasına bağlıdır. $\mathrm{Bu}$ ölçütler inandırıcılık, transfer edilebilirlik (aktarılabilirlik), iç güvenirlik veya tutarlılık ile doğrulanabilirlik-teyit edilebilirlik (confirmability) olarak ifade edilebilir (Fraenkel \& Wallen, 2006; Lincoln \& Guba, 1985). Bu çalışmanın geçerli ve güvenilir olabilmesi için bir dizi önlem alınmıştır. Çalışmanın inandırıcılığının sağlanması için uzman incelemesi stratejisine başvurulmuştur. Matematik eğitimi alanında çalışan bir uzmandan verileri incelemesi istenmiştir. Verilerin \%25'i uzmana verilmiş ve aynı sonuçlara ulaşma durumu incelenmiştir. Fikir birliğine ulaşılan kodlar "görüş birliği", farklı düşünülen kodlar ise "Görüş farklılığı" olarak isimlendirilmiş ve kodlayıcı güvenirliği uzlaşma yüzdesi = Görüş Birliği / (Görüş Birliği + Görüş farklılı̆̆ı) * 100 formülünü yardımıyla bulunmuştur (Miles \& Huberman, 1994). Araştırmacı (yazar) ve uzman arasındaki kodlayıcı güvenirliğinin $\% 90$ olduğu ortaya çıkmıştır. $\mathrm{Bu}$ da çalışmanın geçerli olduğu çıkarımını yapmaya imkan verir (Miles \& Huberman, 1994). Araştırmanın transfer edilebilirliğini sağlamak için de katılımcılar amaçlı bir şekilde seçilmiştir. Araştırmanın tutarlığını sağlayabilmek için araştırmanın nasıl gerçekleştirildiği ayrıntılı bir şekilde okuyucuya sunulmuştur. Ayrıca elde edilen sonuçlar kanıtlarla (doğrudan alıntılarla) desteklenmiştir. Bunun da çalışmanın doğrulanabilir olmasına imkan verdiği söylenebilir (Yin, 2003).

\section{Bulgular}

$\mathrm{Bu}$ kısımda öğretmen adaylarının verilen etkinliklere ilişkin verdikleri cevaplar ölçülmesi hedeflenen bilgi ve beceriler çerçevesinde değerlendirilerek okuyucuya sunulmuştur.

\section{Öğretmen adayları bağlama uygun histogramın eksenlerini isimlendirebilmeye ilişkin hangi bilgi ve becerilere sahiptir?}

Birinci etkinliğin $b$ şıkkı ile dördüncü etkinliğin a şıkkına ilişkin sorular öğretmen adaylarının verilen bağlama uygun histogramın eksenlerini isimlendirebilmeye ilişkin bilgi ve becerilerini ortaya çıkarmak amacıyla sorulmuştur. Öğretmen adaylarının birinci etkinliğin b şıkkına ilişkin verdikleri cevaplar Tablo 3'de ifade edilmiştir. 
Tablo 3. Birinci Etkinliğin b Şıkkına İlişkin Bulgular

\begin{tabular}{|c|c|c|c|}
\hline Cevap Türü & Yatay ve dikey eksenin isimlendirilmesi & Kişi sayısı & Yüzde (\%) \\
\hline \multirow[t]{4}{*}{ Doğru } & $\mathrm{X}$-kolestrol düzeyi & 62 & 94 \\
\hline & Y -frekans-kişi sayısı & & \\
\hline & X -frekans-kişi sayısı & 3 & 1.5 \\
\hline & Y -kolestrol düzeyi & & \\
\hline \multirow[t]{2}{*}{ Yanlış } & X -kolestrol düzeyi & 1 & 4.5 \\
\hline & Y -yaş aralığ 1 (bireylerin yaşları) & & \\
\hline
\end{tabular}

Tablo 3 değerlendirildiğinde öğretmen adaylarının yaklaşık \%95'inin doğru cevap verdiği gözlenmiştir. Öğretmen adaylarının üçü yatay eksen ile dikey eksenin yerlerini değiştirerek cevaplarını vermiştir. Verilen bağlamda "40 yaş ve üzeri" denilerek hedef kitle belirtilmesine rağmen öğretmen adaylarının \%4.5'u histogramın eksenlerini kolestrol düzeyi ve yaş olarak isimlendirmiştir. Bir diğer etkinlik olan dördüncü etkinliğin ilk sorusunda ise öğretmen adaylarından \%85'inin doğru \%15'inin yanlış cevap verdiği gözlenmiştir (Tablo 4).

Tablo 4. Dördüncü Etkinliğin a Şıkkına İlişkin Bulgular

\begin{tabular}{llll}
\hline Cevap Türü & Yatay ve dikey eksenin isimlendirilmesi & Kişi sayısı & Yüzde (\%) \\
\hline Doğru & X -maaşların düzeyi & 56 & 85 \\
& Y - maaşların düzeyinin frekansı & & \\
Yanlış & X - henüz emekli olmamış 40 yaş ve üzeri bireylerin yaşı & 9 & 14 \\
& Y - maaşların düzeyi & 1 & 1 \\
Yanlış & Her ikisi de olur & 1 & 1 \\
\hline
\end{tabular}

İlk etkinliğin b şıkkına ilişkin soruda öğretmen adaylarının \%4.5'u yanlış cevap vermişken, diğer soruda öğretmen adaylarının \%15'inin eksenleri isimlendiremediği gözlenmiştir.

\section{Öğretmen adayları bağlama uygun dağılım grafiği oluşturabilmeye ilişkin hangi bilgi ve becerilere sahiptir?}

Öğretmen adaylarının verilen bağlama uygun dağılım grafiği oluşturabilmeye ilişkin bilgi ve becerilerini değerlendirebilmek amacıyla birinci etkinliğin a şıkkı ile dördüncü etkinliğin $b$ şıkkı sorulmuştur. Birinci etkinliğin a şıkkına ilişkin soruda öğretmen adaylarının uygun dağılım şekline karar vermeleri ve bu süreçte verilen değerleri (ortalama, medyan, standart sapma) dikkate almaları beklenmiştir (bknz. Tablo 5).

Tablo 5. Birinci Etkinliğin a Şıkkına İlişkin Bulgular

\begin{tabular}{|c|c|c|c|c|}
\hline Cevap türü & Dağılım şekli & Gerekçe & $\begin{array}{l}\text { Kişi } \\
\text { sayısı }\end{array}$ & $\begin{array}{l}\text { Yüzde } \\
(\%)\end{array}$ \\
\hline \multirow[t]{2}{*}{ Doğru } & Normal & $\begin{array}{l}\text { Medyan ve aritmetik ortalama değerleri birbirine } \\
\text { yakındır -s.s. ile ilişkilendirme var }\end{array}$ & 14 & 21.3 \\
\hline & & $\begin{array}{l}\text { Medyan ve aritmetik ortalama değerleri birbirine } \\
\text { yakındır - s.s. ile ilişkilendirme yok }\end{array}$ & 16 & 24.3 \\
\hline Yanlış & Sola çarpık & Aritmetik ortalama medyandan küçüktür & 31 & 46.9 \\
\hline Yanlış & $\begin{array}{l}\text { Hem normal } \\
\text { hem sola çarpık }\end{array}$ & $\begin{array}{l}\text { Normal dağılım olabilir medyan ile aritmetik } \\
\text { ortalama yakındır. Sola çarpıkta olabilir çünkü } \\
\text { medyan ortalamanın üzerindedir }\end{array}$ & 1 & 1.5 \\
\hline Yanit yok & - & - & 4 & 6 \\
\hline
\end{tabular}

Tablo 5 den hareketle öğretmen adaylarının \%46.9'unun “aritmetik ortalama medyandan küçükse dağılımın çarpıktır" ifadesini aşırı genellemiş olduğu ve bu süreçte standart 
sapmanın dikkate alınması gerektiğini göz ardı ettikleri ortaya çıkmıştır. Öğretmen adaylarının yaklaşık yarısı ise (\%45.6) doğru cevap vermiştir. Ancak bu doğru cevabı verenlerin yarısından fazlası (\%53) cevabını standart sapma ile ilişkilendirmemiştir. Örneğin Ö1 "kolestrol düzeyinin medyanı ve ortalaması birbirinden çok farklı olmamasından dolayı normal dă̆ılımdır." ifadesini kullanmıştır. Ancak bu ifade de neye göre bu iki değerin birbirine yakın olduğunu ifade etmemiştir. Doğru cevap veren ve cevabını standart sapma ile ilişkilendiren öğretmen adaylarının (\%47) açıklamalarında örneğin Ö31 "Normal dağılımdır. Çünkü ortalama ile medyan arasındaki fark standart sapmaya göre oldukça az" ifadesini kullanırken, Ö43 "Kolestrol düzeylerinde medyan ve ortalama birbirine çok yakındır. Ayrıca standart sapmada 20'dir. Yani verilerin ortalamaya olan uzaklı̆̆g (standart sapma) 20'dir. Bu yüzden de dağllım şekli normal dağılım olur." ifadelerini kullandıkları gözlenmiştir. Öğrencilerin \%6 s1 ise herhangi bir cevap verememiştir.

Benzer amaçla sorulan dördüncü etkinliğin $b$ şıkkına öğretmen adaylarının verdikleri cevaplar Tablo 6' da sunulmuştur.

\section{Tablo 6. Dördüncü Etkinliğin b Şıkkına İlişkin Bulgular}

\begin{tabular}{|c|c|c|c|c|}
\hline $\begin{array}{l}\text { Cevap } \\
\text { Türü }\end{array}$ & Dağılım şekli & Gerekçe & $\begin{array}{l}\text { Kişi } \\
\text { say1s1 }\end{array}$ & $\begin{array}{l}\text { Yüzde } \\
(\%)\end{array}$ \\
\hline Doğru & Normal & $\begin{array}{l}\text { Çünkü seçtiğimiz örneklemde çok düşük ve çok } \\
\text { yüksek maaş alanların yanında çoğu birbirine yakın } \\
\text { maaşlar alır. }\end{array}$ & 17 & 26 \\
\hline Yanlış & Sağa çarpık & $\begin{array}{l}\text { Çünkü maaş düzeyi asgari ücret olan kişi sayısının en } \\
\text { fazla olacağını düşünüyorum. Maaş düzeyi arttıkça } \\
\text { da kişi sayısı azalacaktır. Uç noktalarda çok fazla } \\
\text { insan yok. }\end{array}$ & 19 & 29 \\
\hline Yanlış & Sola çarpık & $\begin{array}{l}\text { İnsanların çalışma süreleri arttıkça aldıkları maaş } \\
\text { seviyeleri de artar. }\end{array}$ & 7 & 11 \\
\hline Yanlış & $\begin{array}{l}\text { Hem sağa hem } \\
\text { sola çarpik }\end{array}$ & $\begin{array}{l}\text { Seçtiğim örnekleme göre değişeceği için sağa } \\
\text { çarpıkta olabilir sola çarpıkta olabilir. }\end{array}$ & 7 & 11 \\
\hline Yanlış & $\begin{array}{l}\text { Sağa, sola, } \\
\text { normal }\end{array}$ & $\begin{array}{l}\text { Gelişmiş ülkelerde sola çarpık bir dağılım } \\
\text { gözlenirken, orta ekonomik düzeydeki bir ülkede } \\
\text { simetrik, düşük ekonomik düzeydeki ülkelerde ise } \\
\text { sağa çarpık bir dağılım gözlenir. }\end{array}$ & 5 & 8 \\
\hline Yanlış & $\begin{array}{l}\text { Normal ya da } \\
\text { sola çarpık }\end{array}$ & $\begin{array}{l}\text { Normal dağılım olabilir. Uç noktalar elbette olacak } \\
\text { herkes } 40 \text { yaş ve üstü olacağı için çok fazla yaştan } \\
\text { kaynaklı zam da etkilemez. Eğer ki etkilerse sola } \\
\text { çarpık bir dağılımda olabilir. }\end{array}$ & 1 & 1.5 \\
\hline Yanlış & $\begin{array}{l}\text { Normal ya da } \\
\text { sağa çarpık }\end{array}$ & $\begin{array}{l}\text { Normal dağılım olabilir. Çünkü belli bir ortalama } \\
\text { ücrette maaş alan kişi sayısı fazladır. Çok düşük maaş } \\
\text { alan ve çok yüksek maaş alan kişi sayısı daha azdır. } \\
\text { Ama asgari ücretten daha az maaş alınmayacağ } 1 \text { ya } \\
\text { da alan bireylerin az olacağını da düşünürsek, yani } \\
\text { çoğu kişi asgari ücret düzeyinde maaş alıyor dersek } \\
\text { dağılımın şekli sağa çarpık olur. }\end{array}$ & 1 & 1.5 \\
\hline Yanlış & $\begin{array}{l}\text { Bir sürü farklı } \\
\text { grafik }\end{array}$ & Dağılımın şekli kişi sayısına bağlı olarak değişir. & 3 & 4 \\
\hline Yanlış & $\begin{array}{l}\text { Dağılım şekli } \\
\text { oluşturamayız }\end{array}$ & $\begin{array}{l}\text { Veri grubunun örneklemini nerden seçtiğimizi } \\
\text { bilemediğimiz için dağılımın şeklini bilemeyiz }\end{array}$ & 6 & 8 \\
\hline
\end{tabular}


Elde edilen bulgular öğretmen adaylarının sadece \%26'sının doğru cevap verdiğini ortaya koymuştur. Öğretmen adaylarının \%29'u sağa çarpık dağılım cevabını verirken, \%11'i sola çarpık dağılım cevabını vermiştir. Öğretmen adaylarının \%26'sı ise sağa, sola çarpık veya normal dağılım olabileceğini belirtirken \%8'i dağılım grafiği oluşturulamayacağını söylemiştir. \%4'ü ise bir sürü farklı dağılım grafiği oluşturulabileceğini ifade etmiştir. Öğretmen adaylarının ilk soruda yaklaşık yarısı (\%45.6) doğru cevap verirken, ikinci soruda bu oranın yaklaşık dörtte bir (\%26) olduğu gözlenmiştir.

\section{Öğretmen adayları verilen dağılım grafiğinden yola çıkarak gerçek yaşam durumlarını nasıl değerlendirmektedir?}

Öğretmen adaylarının dağılım grafiğinden yola çıkarak gerçek yaşam durumlarını değerlendirebilmelerinin beklendiği soruya (birinci etkinlik üçüncü soru) ilişkin öğretmen adaylarının cevapları Tablo 7'de sunulmuştur.

\section{Tablo 7. Dağılım Grafiğinden Yola Çıkarak Gerçek Yaşam Durumlarını Değerlendirebilmeye İlişkin Bulgular}

\begin{tabular}{lllll}
\hline Cevap Türü & Değer Türü & Açıklama Türü & Kişi sayısı & Yüzde (\%) \\
\hline Doğru & Olağandışı değil & Yeterli açıklama & 3 & 4,5 \\
& & Yeterli olmayan/eksik açıklama & 5 & 7,5 \\
Yanlış & Olağandışı & & 56 & 85 \\
Yanlış & Her ikisi olabilir & & 1 & 1.5 \\
Yanlış & Yanıt yok & & 1 & 1.5 \\
\hline
\end{tabular}

Tablo 7'de gösterildiği gibi öğretmen adaylarının \%12'sinin doğru cevap verebildiği ortaya çıkmıştır. Doğru cevap veren öğretmen adaylarından sadece \%37'si cevaplarını doğru bir şekilde gerekçelendirebilmiştir. Diğer doğru cevap veren öğretmen adaylarının eksik ya da yeterli olmayan açıklamalarla cevaplarını gerekçelendirdikleri gözlenmiştir. Öğretmen adaylarının \%85'i 188'i olağan dışı bir değer olarak ifade etmiş ve yanlış cevap vermiştir. Bir öğretmen adayı yanıt vermezken, bir öğretmen adayı hem olağan hem de olağan dişı değer olduğunu ifade etmiştir. Öğretmen adaylarının cevaplarını gerekçelendirmeleri istendiğinde ise öğretmen adaylarının sadece üçünün cevabını doğru bir şekilde gerekçelendirebildiği gözlenmiştir. Doğru gerekçelendiren öğretmen adaylarının cevaplarını z puanını dikkate alacak şekilde açıklama yaptıkları gözlenmiştir (bkz. Şekil 1,2,3).

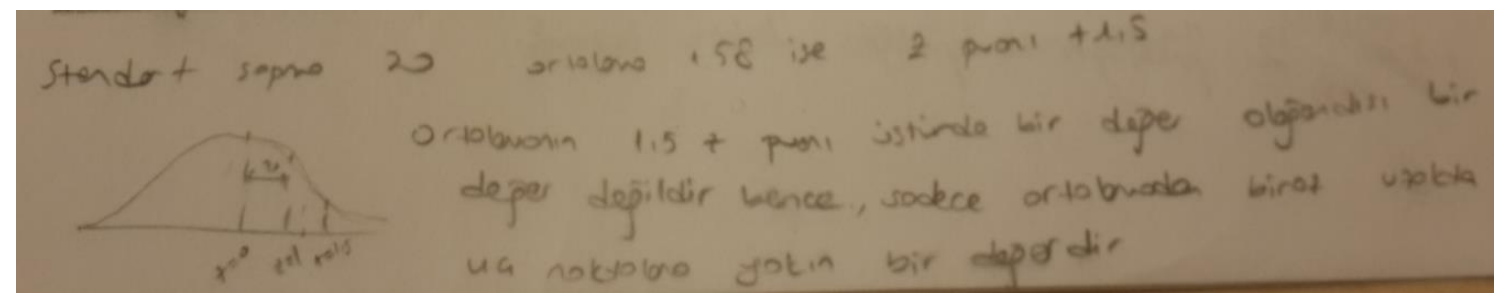

Şekil 1. Ö2'nin doğru gerekçesi 


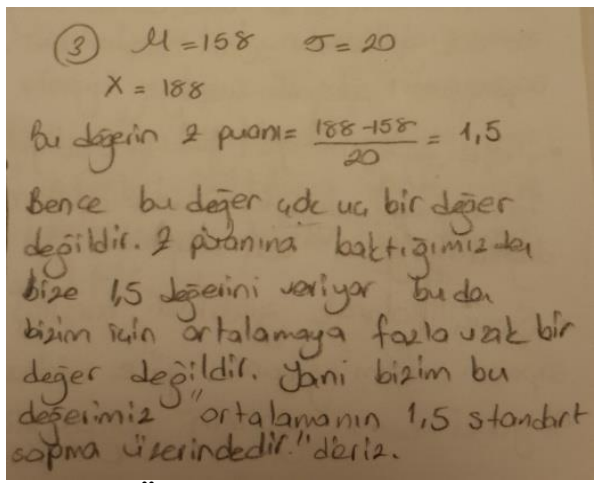

Şekil 2. Ö52'nin doğru gerekçesi

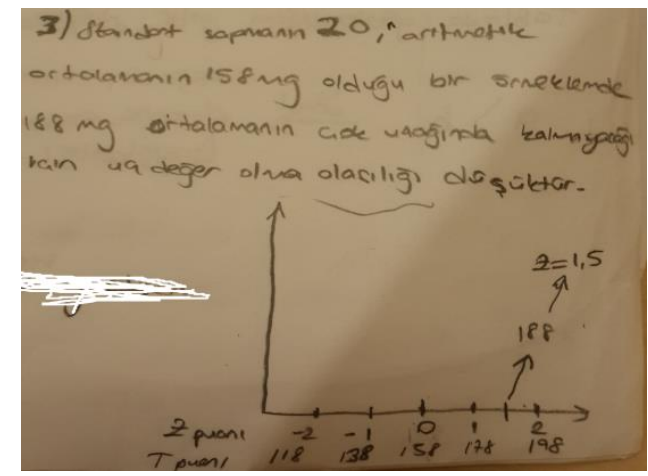

Şekil 3. Ö64'ün doğru gerekçesi

Beş öğretmen adayı ise doğru cevap vermesine rağmen cevabını yeterli olmayan ya da eksik açıklamalarla gerekçelendirmişlerdir. Örneğin Ö11 cevabını gerekçelendirirken "Hayır değildir. Çünkü ortalama değeri 158 dir. Medyan 160 dır. $188 \mathrm{mg}$ ortalama değeri $158 \mathrm{mg}$ ya çokta uzakta değildir." şeklinde olağan dışı değer olmadığını ifade etmiştir. Ö33 de verilen değeri standart sapma ile ilişkilendirerek açıklamasını yapmasına rağmen standart sapmayı neye göre kıyasladığını ifade etmemiştir. Cevabı Şekil 4'de gösterilmiştir.

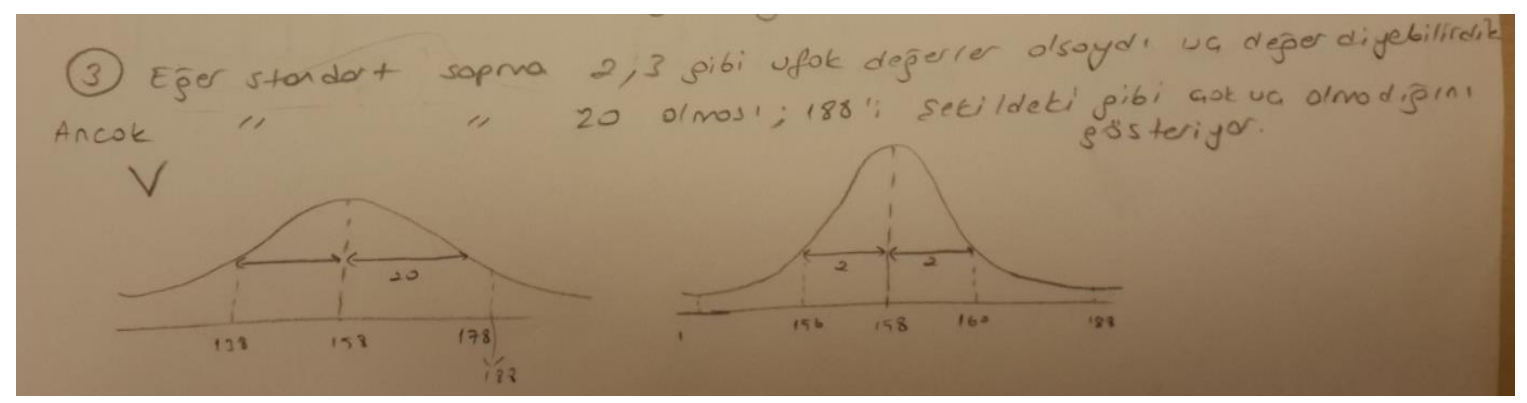

\section{Şekil 4. Ö33'ün yaptığı eksik gerekçe}

188 değerini olağandışı bir değer olduğunu ifade eden öğretmen adayları (\%85) cevaplarını açıklarken $\mathrm{Z}$ puanını dikkate almışlar, $+1 \mathrm{Z}$ ile $-1 \mathrm{Z}$ puanların dışındaki değerleri uç değer olarak kabul etmişlerdir. Örneğin Ö4 "evet dă̆glımın ortalama değeri 158 dir. Puanlar 138 ile 178 arasında yoğunluktadır. Bu nedenle 188 uç bir değerdir." şeklinde ifade etmiştir. Bunun yanında bazı öğretmen adaylarının ortalama ve standart sapmayı dikkate almalarına rağmen 188 değerinin olağan dışı olduğunu "Evet çünkü ortalamaya biraz uzak ve standart sapmaya göre değerlendirdiğimizde biraz büyük bir değer olduğunu görüyoruz.” (Ö13) şeklinde sezgisel olarak açıklamıştır.

\section{Öğretmen adayları dağılımın grafiksel gösterimi ile değişkenlik arasında nasıl bağlantılar kurmaktadır?}

Öğretmen adaylarına yöneltilen ikinci ve üçüncü etkinlikle dağılımın grafiksel gösterimi ile değişkenlik arasındaki bağlantıyı nasıl kurdukları incelenmiştir. İkinci etkinliğe ilişkin öğretmen adaylarının verdikleri cevaplar Tablo 8'de gösterilmiştir. 
Tablo 8. İkinci Etkinliğe İlişkin Bulgular

\begin{tabular}{llll}
\hline Cevap Türü & Cevap & Kişi sayıs1 & Yüzde (\%) \\
\hline Doğru & $\mathrm{d}$ & 64 & 97 \\
Yanlış & $\mathrm{c}$ & 1 & 1,5 \\
Boș & - & 1 & 1,5 \\
\hline
\end{tabular}

İkinci etkinlikte öğretmen adaylarının çoğunun (\%97) doğru cevaba ulaştığı ve cevaplarını doğru ifadelerle gerekçelendirebildikleri gözlenmiştir. Bir öğretmen adayı yanlış cevap verirken bir öğretmen adayı da cevap vermemiştir (bknz. Tablo 8). Doğru cevap veren öğretmen adaylarının gerekçelerini de doğru ifadeler kullanarak yaptıkları gözlenmiştir. Öğretmen adaylarının çoğu "Çünkü çam ăgacından üretilen pencere çerçevesinin genişlik dă̆ılımına baktı̆̆ımız zaman daha dardır, fazla yayılmamıştır. Ama meşe ağacınınkine baktığımızda daha geniş bir alana yayılmıştır. Çünkü meşe ă̆acından üretilen pencere çerçevesinin genişlik dă̆ılımı daha geniş bir grafikle ifade edilmiş. Daha değişken olduğunu çıkarabiliriz. Aynı zamanda meşe ağacından üretilen pencere çerçevesinin genişlik dağılımı daha farklı puanlar içerir. Bu da değişkenliği artırır." şeklinde doğru bir gerekçe ile doğru cevaba ulaşmıştır. Yanlış cevap veren öğretmen adayı ise yatay eksendeki değerlere bakmak yerine dikey eksendeki değerlere bakmayı tercih etmiş ve değerleri kıyaslamıştır. Cevabını " $c$ şıkkl. Çünkü çam ă̆acında çok yüksek bir medyan değeri vardır. Bu medyanın çevresinden değerler oldukça uzaklaşmıştır. Benzer değerler çok fazla değildir. Fakat meşe ă̆acında değerler medyan çevresinde toplanmıştır. Benzer değerler için geniş bir aralık oluşmuştur." şeklinde ifade etmiştir. Bir diğer etkinlik olan üçüncü etkinliğe ilişkin ilk şıkkına ilişkin öğretmen adaylarının verdikleri cevaplar Tablo 9'da sunulmuştur.

Tablo 9. Üçüncü Etkinliğin a Şıkkına İlişkin Bulgular

\begin{tabular}{llll}
\hline Cevap Türü & Cevap & Kişi sayısı & Yüzde (\%) \\
\hline Doğru & $\mathrm{b}$ & 56 & 85 \\
Yanlış & $\mathrm{a}$ & 10 & 15 \\
\hline
\end{tabular}

Burada öğretmen adaylarının çoğunluğunun (\%85) doğru cevap verebildiği gözlenmiştir. Öğretmen adaylarından verdikleri cevapları gerekçelendirmeleri istendiğinde ise sadece \%3'ünün cevabını doğru gerekçelendirebildiği dikkati çekmiştir. Bu soruya yanlış cevap veren öğrencilerin hepsinin gerekçelendirmeyi de yanlış yaptığ 1 ortaya çıkmıştır. Öğretmen adaylarının cevaplarını gerekçelendirdikleri üçüncü etkinliğin $b$ şıkkına ilişkin elde edilen bulgular Tablo 10'da ifade edilmiştir.

Tablo 10. Üçüncü Etkinliğe İlişkin Bulgular

\begin{tabular}{|c|c|c|c|c|}
\hline $\begin{array}{l}\text { Cevap } \\
\text { Türü }\end{array}$ & Cevap & Gerekçe & $\begin{array}{l}\text { Kişi } \\
\text { sayısı }\end{array}$ & $\begin{array}{l}\text { Yüzde } \\
(\%)\end{array}$ \\
\hline \multirow[t]{4}{*}{ Doğru } & $d-b$ & $\begin{array}{l}\text { Çünkü bu dağılımdaki değerler merkezden farklı değerdedir } \\
\text { ve bu dağılım daha geniştir. (Doğru gerekçe) }\end{array}$ & 2 & 3 \\
\hline & $\mathrm{b}$ & Bu dağılım daha geniştir (Eksik gerekçe) & 2 & 3 \\
\hline & $\mathrm{c}$ & $\begin{array}{l}\text { Çünkü bu dağılım daha fazla farklı sayıda puanlar içerir. } \\
\text { (Yanlış gerekçe) }\end{array}$ & 50 & 76 \\
\hline & & $\begin{array}{l}\text { B grafiğinin standart sapmanın fazla olması merkezdeki } \\
\text { değerlerin fazla olduğunu gösterir. Ayrıca uç değerlerinde } \\
\text { var olduğunu gösterir. (Yanlış gerekçe) }\end{array}$ & 1 & 1.5 \\
\hline Yanlış & $\mathrm{a}$ & Çünkü bu dağılım daha fazla farklı sayıda puanlar içerir & 11 & 16.5 \\
\hline
\end{tabular}


Elde edilen bulgular öğretmen adaylarının \%83'ünün doğru \%17'sinin yanlış cevap verdiğini ortaya çıkarmıştır. Doğru cevap veren öğretmen adaylarının gerekçelerini açıklarken çeşitli yanlış anlamalarının olduğu ortaya çıkmıştır. İki öğretmen adayı (Ö10, Ö25) hariç diğerleri cevaplarını gerekçelendirirken "Çünkü bu dă̆glım daha fazla farklı sayıda puanlar içerir." ifadesini seçmiştir. Burada değişkenliği düzensizlik olarak algıladıkları söylenebilir. Ayrıca histogram ile ifade edilen farklı grupları bireysel puan olarak düşündükleri söylenebilir. Bunun yanında Ö66 "B grafiğinin standart sapmanın fazla olması merkezdeki değerlerin fazla olduğunu gösterir. Ayrıca uç değerlerinde var olduğunu gösterir. "şeklinde seçenekler dışında bir ifade ile cevabını gerekçelendirmiştir. Burada da standart sapma ile ilgili bazı yanlış anlamalarının olduğu gözlenmiştir. Cevabını doğru gerekçelendiren öğretmen adaylarının ise "Çünkü bu dă̆llımdaki değerler merkezden farklı değerdedir ve bu dă̆llım daha geniștir" ifadelerini seçtikleri gözlenmiştir. Yanlış cevap veren öğretmen adaylarının yine bu iki temel yanılgıya sahip oldukları ortaya çıkmıştır.

\section{Tartışma ve Sonuç}

$\mathrm{Bu}$ çalışmada öğretmen adaylarının dağılım ve bununla ilişkili kavramları (değişkenlik, histogram) nasıl algıladığı ve anlamlandırdığını ortaya çıkarmak amaçlanmıştır. Bu amaçla dört alt probleme cevap aranmıştır. Birinci alt problemde öğretmen adaylarının verilen bağlama uygun histogramın eksenlerini isimlendirebilmeye ilişkin ne gibi bilgi ve becerilere sahip olduklarına odaklanılmıştır. Bu probleme cevap verebilmek için iki soru sorulmuş, farklı bağlamlarda verilen örneklemlere ilişkin histogramların eksenlerini isimlendirilmeleri istenmiştir. İlk soruda öğretmen adaylarının \%95.5'i eksenleri doğru isimlendirebilmişken, $\% 4.5$ 'u yanlış isimlendirilmiştir. Diğer soruda ise \%85'inin doğru \%15'inin yanlış cevap verdiği gözlenmiştir. Yanlış cevap veren öğretmen adaylarının grafiğin eksenlerini henüz emekli olmamış 40 yaş ve üzeri bireylerin yaşı ile maaşların düzeyi olarak isimlendirdiği gözlenmiştir. Burada iki çarpıcı sonucun ortaya çıktığı söylenebilir. Bunlardan ilki verilen örneklemin "40 yaş ve üzeri" şeklinde sınırlandırılmış olmasına rağmen öğretmen adaylarının bazıları seçtikleri eksen isimlerini bu doğrultuda değerlendirmiş olmalarıdır. Sorulan diğer soruda ilk soruya göre öğretmen adaylarının daha fazla yanlış yapmış olmaları dikkati çeken bir diğer sonuçtur. Öğretmen adaylarının histogramın iki değişkene sahip iki boyutlu bir grafik olması gerektiğini düşündükleri ve bu yüzden iki değişkenli saçılma grafiği olarak yorumlanması gerektiğini düşünme eğiliminde oldukları gözlenmiştir. Yani histogramı iki değişken arasındaki ilişkiyi ifade eden bir grafik olduğunu düşünmüşlerdir. Alan yazında bunu desteklerde nitelikte bulgulara ulaşmışlardır (Lee \& Meletiou-Mavrotheris, 2003; Zaidan, Ismail, Yusof \& Kashefi, 2012). Yapılan çalışmalar gerek öğretmenlerin gerekse öğretmen adaylarının histogram grafiğini anlamlandırmakta sorun yaşadıklarını ortaya koymaktadır (Bruno \& Espinel, 2009; Lee \& Meletiou-Mavrotheris, 2003).

$\mathrm{Bu}$ çalışmanın ikinci alt probleminde öğretmen adaylarının bağlama uygun dağılım grafiğini tayin edebilmeye ilişkin bilgi ve becerileri incelenmiştir. Aritmetik ortalama değerinin medyan değerinden küçük olduğu durumlarda dağılımın şekline karar verirken standart sapma değerini nasıl dikkate aldıkları değerlendirilmiştir. Öğretmen adaylarının \%46.9'u aritmetik ortalama medyandan küçükse dağılım çarpıktır ifadesini aşırı genellemiş bu ifadenin değerlendirilmesi sırasında standart sapmanın dikkate alınması gerektiğini göz ardı etmiştir. Sadece \%21.3'ünün dağılımın şekline karar verirken standart sapmanın rolüne dikkat çektiği 
gözlenmiştir. Doğru cevap veren öğretmen adaylarının \%53'ü ise gerekçelerini standart sapma ile ilişkilendirememiştir. Öğretmen adaylarının yaklaşık yarısı (\%48.4) standart sapma ifadesini göz ardı etmiş sadece aritmetik ortalama ve medyan değerlerine bakarak dağılımın şekline karar vermiştir. Kalan \%6'sı ise cevap verememiştir. Ayrıca standart sapmanın gerçek yaşam durumlarına ilişkin bağlamların dağılımına karar vermede nasıl bir role sahip olduğunu dikkate almakta zorlanmışlardır. Öğretmen adaylarının sadece verilen değerleri dikkate alarak değerlendirme yaptıkları ve bazı ifadeleri aşırı genelledikleri gözlenmiştir. Ayrıca öğretmen adaylarının dağılım kavramıyla ilişkili değerleri bir arada ele almakta ve karar vermekte zorlandıkları gözlenmiştir. Böyle bir sonucun ortaya çıkmasına öğretmen adaylarının öğretim yaşantılarının zemin hazırlayabileceği söylenebilir. Çünkü öğretim sürecinde standart sapmanın hesaplanmasına ağırlık verilmesi, bu kavramın bağlam içerisinde nasıl bir rol üstlendiğine ilişkin çalışmalara değinilmemesi bu kavramın ne anlama geldiği konusunda eksik kalmalarına neden olmaktadır (delMas \& Liu, 2005). Bu da bilgilerinin kaygan olmasına ve çeşitli zorluklar yaşamalarına neden olmaktadır (Garfield, 2003). Benzer amaçla sorulan diğer soruda ise öğretmen adaylarının sadece \%26'sı doğru cevap vermiştir. Öğretmen adaylarının yaptıkları yanlışların merkezi limit teoremine ilişkin bilgi eksikliklerinden kaynaklandığı düşünülebilir (Lee \& Meletiou-Mavrotheris, 2003). Alan yazın değerlendirildiğinde benzer noktalara vurgu yapılmış, katılımcıların standart sapmanın günlük yaşam durumlarına ilişkin bağlamlarda nasıl kullanılması gerektiğini yorumlamakta zorlandıkları gözlenmiştir (Lee \& Meletiou-Mavrotheris, 2003; Zaidan ve diğerleri, 2012). Ayrıca birinci etkinlikte dağılımın şeklini doğru tayin edip eksen isimlerini yanlış tayin eden bir öğretmen adayı varken (Ö47), dördüncü etkinlikte dağılımın şeklini doğru tayin edip eksenleri yanlış tayin eden iki öğretmen adayı (Ö32, Ö47) olduğu gözlenmiştir. Eksenleri yanlış tayin eden öğretmen adaylarının çoğunlukla dağılımın şeklini de yanlış tayin ettiği gözlenmiştir. Histogramı iki değişken arasındaki ilişkiyi ifade eden bir grafik olduğunu düşünmelerinin böyle bir sonucun ortaya çıkmasını tetiklediği düşünülebilir (Lee \& Meletiou-Mavrotheris, 2003). Sağa ya da sola çarpık diyen öğretmen adaylarının histogram ile saçılma grafiğinin karıştırdıkları, dağılım kavramının ne anlama geldiğini anlamlandıramadıkları söylenebilir. Öğretmen adaylarının bağlam değiştikçe grafiği uygun şekilde isimlendirmekte ve dağılımın şekline karar vermekte zorlanmaları ortaya çıkan bir diğer önemli sonuçtur. Araştırmalarda bu sonucu destekler nitelikte bulgulara ulaşılmış, öğretmenlerin farklı bağlamların dağılımını değerlendirmekte zorlandıkları ve tutarsız düşünceler ürettiklerini ortaya koymuştur (Mickelson \& Heaton, 2004).

$\mathrm{Bu}$ çalışmanın üçüncü alt probleminde öğretmen adaylarından dağılım grafiğinden yola çıkarak gerçek yaşam durumlarını değerlendirmeleri istenmiştir. Burada öğretmen adaylarının sadece \%12'si doğru cevap verebilmiştir. Doğru cevap veren öğretmen adaylarının da sadece \%37'si ifadesini doğru gerekçelendirebilmiştir. Doğru gerekçelendiren öğretmen adayları cevaplarını z puanı ile ilişkilendirerek değerin uç olup olmadığını tayin ederken, yeterli olmayan ya da eksik gerekçelendiren öğretmen adayları cevaplarını standart sapmayı dikkate alarak ilgili değerin uç olmadığını ifade etmiştir. Yanlış cevap veren öğretmen adaylarının ise dağılımı $+1 Z$ ile $-1 Z$ puanı aralığında değerlendirmişler bunun dışındaki değerlerin uç değer olacağını düşünmüşlerdir. Burada öğretmen adaylarının standart sapmanın dikkate alınması gerektiğini fark etmelerine rağmen bunu gerçek yaşam durumlarına transfer edemedikleri gözlenmiştir. Öğretmen adaylarının olasılıksal akıl yürütmek yerine deterministik akıl yürütmeye eğilimli olmalarının böyle bir sonucun ortaya çıkmasına zemin hazırladığı söylenebilir (Biehler, 1994). 
Ayrıca veri dağılımının bütününe bakmak yerine sadece belli değerlere odaklanmalarının böyle bir sonucun ortaya çıkmasını tetiklediği söylenebilir. Araştırmalarda benzer noktalara vurgu yapmış dağılımın bütününden yola çıkarak değerlendirme yapılmamasının yanlış çıkarımlara sebebiyet verebileceği vurgulanmıştır (Groth \& Meletiou-Mavrotheris, 2018; Makar \& Confrey, 2005).

$\mathrm{Bu}$ çalışmanın dördüncü alt probleminde ise öğretmen adaylarının dağılımın grafiksel gösterimi ile değişkenlik arasındaki bağlantıyı kurabilmeye ilişkin bilgi ve becerilerine odaklanılmıştır. Bu amaçla tamamladıkları ikinci etkinliğe öğretmen adaylarının \%097'si doğru cevap vermişken, üçüncü etkinlikte bu oran $\% 85$ 'e düşmüştür. Doğru cevap veren öğretmen adaylarının Garfield ve Ben-Zvi'nin (2005) değişkenlik için önemli olduğunu düşündükleri anahtar fikirlerin bazılarına sahip oldukları değişkenlikle ilgili sezgisel fikir geliştirebildikleri ve grafikleri değişkenliği dikkate alarak kıyaslayabildikleri gözlenmiştir. Doğru cevap veren öğretmen adaylarından bazıları da cevapların gerekçelendirirken sadece "çünkü bu daha fazla geniştir" ifadesini seçmişlerdir. Burada bu ifade doğru olmasına rağmen yeterli değildir. Araştırmacıların da aralığa göre dağılımın değişkenliğinin belirlenebileceğini ancak bunun tek başına yeterli olmadığını vurguladıkları gözlenmiştir (Vermette \& Savard, 2019). Doğru cevap vermesine rağmen yanlış akıl yürüterek cevabını gerekçelendiren öğretmen adaylarının değişkenliği düzensiz olarak algıladıkları ve histogramlarda gösterilen farklı grupları bireysel puanlar olarak algıladıkları ortaya çıkmıştır. Alan yazın incelendiğinde benzer bulgulara ulaşılmış öğretmen adayı/öğretmenlerin dağılımın merkezi ve değişkenliğini çeşitli kavram yanılgıları ve yanlış akıl yürütmelerle değerlendirdikleri ortaya çıkmıştır (Cooper \& Shore 2010; delMas \& Liu 2005; Lee \& Meletiou-Mavrotheris, 2003; Mickelson \& Heaton, 2004; Reading \& Shaugnessy, 2004; Garfield \& Ben-Zvi, 2008b). Örneğin Lee ve MeletiouMavrotheris (2003) gerçekleştirdiği 162 üniversite öğrencisiyle gerçekleştirdiği çalışmasında iki histograma ilişkin dağılımları kıyaslarken sütun uzunluklarının karşılaştırılmasına odaklanıldıkları ortaya çıkarmıştır. Böyle bir sonucun ortaya çıkmasında öğretmen adaylarının istatistiksel ölçümleri algoritmalarla sınırlı görmelerinin etkisinin olduğu düşünülebilir (Mickelson \& Heaton, 2004). Yanlış cevap veren öğretmen adaylarının da benzer yanlış anlamalara sahip oldukları gözlenmiştir. Değişkenliği değerlendirirken yatay eksendeki değerlere bakmak yerine dikey eksendeki değerlere göre yorum yapmışlardır. Alan yazında da benzer noktalara vurgu yapılmış öğretmen adaylarının değişkenliği çubukların yüksekliği olarak algıladıkları ve çubukların yükseklikleri arasındaki farka göre değerlendirdikleri gözlenmiştir (Cooper \& Shore 2008).

Elde edilen bulgular genel olarak değerlendirildiğinde öğretmen adaylarının başarı durumlarının yüksek olmasına rağmen istatistiksel kavramlara ilişkin bilgilerinde çeşitli eksiklikler olduğu söylenebilir. Alan yazın değerlendirildiğinde benzer noktalara vurgu yapılmış, istatistiğe ilişkin kursları başarıyla tamamlayan bireylerin bile kavramları anlamlandırmakta zorlandıkları ifade edilmiştir (Garfield ve diğerleri, 2007; Mathews \& Clark 2003). Öğretmen adayları dağılım ve bununla ilişkili önemli istatistiksel kavramlar (histogram, eksenler, değişkenlik) arasındaki ilişkileri değerlendirmekte yetersiz kalmışlardır. Örneğin histogramın eksenlerini tayin etmekte zorlanan bir öğretmen adayının dağılımın şekli ve değişkenliğine ilişkin yorum yapmakta da zorlandığı söylenebilir. Alan yazın da benzer noktalara vurgu yapmış bir kavramda var olan eksikliğin diğer kavram hakkında değerlendirme yapabilmeye engel olabileceğine dikkat çekmiştir (Bakker, 2004; Leavy, 2006; Garfield \& Ben- 
Zvi, 2008a; Pfannkuch \& Reading, 2006; Reading \& Reid, 2006; Shaughnessy, 2007). İstatistik öğretiminin kalitesini büyük oranda öğretmenin bilgisinin şekillendirdiği düşünülürse öğretmen adaylarının bilgilerinde olan bu eksikliklerinin üstesinden gelebilmek için merkezi eğilim ve yayılım ölçüleri ile grafikler arasındaki ilişkileri fark etmelerine yönelik etkinliklerle meşgul olmaları ve bu kavramlar üzerine tartışmaları önerisi dile getirilebilir. Kavram üzerine tartışmanın istatistiksel kavramlar ve bu kavramlar arasındaki ilişkilerin ne anlama geldiği konusunda destekleyici olduğu vurgulanmaktadır (Makar \& Confrey, 2005; Vermette \& Savard, 2019). Yine bu ilişkiler üzerine çalışmalarını sağlayacak ders tasarlamaları yaşadıkları zorlukların üstesinden gelmek için diğer bir öneri olabilir. Araştırmalar bu tarz etkinliklerle meşgul olmanın öğretmen adaylarının kavramlar arasındaki bağlantıları keşfetmelerini destekleyeceğini vurgulamaktadır (Ben-Zvi, 2004; Garfield \& Ben-Zvi, 2008c). Ayrıca bilgisayar destekli istatistik yazılım programlarının değişkenliğin kavramsal olarak ne anlama geldiği konusunda bireylere yol gösterici olabileceği ifade edilmektedir (Canada, 2004). 


\section{Kaynakça}

Asworth, P. \& Lucas, U. (1998). What is 'world' of phenomenography?. Scandinavian Journal of Educational Research, 42(4), 415-431.

Ball, D. L. \& McDiarmid, G. W. (1990). The subject-matter preparation of teachers. In W. R. Houston and M. H. J. Sikula (Eds.), Handbook of research on teacher education (pp. 437-449). New York: Macmillan.

Ball, D. L., Thames, M. H., \& Phelps, G. (2008). Content knowledge for teaching: What makes it special? Journal of Teacher Education, 59(5), 389-407.

Bakker, A. (2004). Reasoning about shape as a pattern in variability. Statistics Education Research Journal, 3(2), 64-83.

Bakker, A. \& Gravemeijer, K. P. E. (2004). Learning to reason about distribution. In D. Ben-Zvi \& J. Garfield (Eds.), The challenge of developing statistical literacy, reasoning and thinking (pp. 147168). Dordrecht: Springer Netherlands.

Ben-Zvi, D. (2004). Reasoning about variability in comparing distributions. Statistics Education Research Journal, 3(2), 42-63.

Biehler, R. (1994). Probabilistic thinking, statistical reasoning and the search for causes: Do we need a probabilistic revolution after we have taught data analysis? In J. Garfield (Ed.), Research Papers from The Fourth International Conference on Teaching Statistics, Marrakech, 1994. Minneapolis, MN: University of Minnesota.

Borko, H., Eisenhart, M., Brown, C. A., Underhill R. G., Jones, D., et. al. (1992). Learning to teach hard mathematics: Do novice teachers and their instructors give up too easily? Journal for Research in Mathematics Education, 23(3), 194-222.

Bruno, A. \& Espinel, M. C. (2009). Construction and evaluation of histograms in teacher training. International Journal of Mathematical Education in Science and Technology, 40(4), 473-493.

Canada, D. (2004). Elementary preservice teachers' conceptions of variation. Unpublished doctoral dissertation, Portland State University, Portland.

Chaphalkar, R. \& Leary, C. (2014), "Introductory Statistics Students' Conceptual Understanding of Variation and Measures of Variation in a Distribution," in Sustainability in Statistics Education. Proceedings of the Ninth International Conference on Teaching Statistic, eds. K. Makar, B. de Sousa, and R. Gould, International Association for Statistical Education.

Cooper, L. L. \& Shore, F. S. (2008). Students' misconceptions in interpreting center and variability of data represented via histograms and stem-and-leaf plots. Journal of Statistics Education, 16(2), 113.

Cooper, L. \& Shore, F. (2010), The effects of data and graph type on concepts and visualizations of variability, Journal of Statistics Education, 18, 1-16.

Creswell, J. W. (2013). Research design: Qualitative, quantitative, and mixed methods approaches. Sage publications.

delMas, R.C. \& Liu, Y. (2005). Exploring Students' Conceptions of the Standard Deviation. Statistics Education Research Journal, 4(1), 55-82.

Fraenkel, J. R., \& Wallen, N. E. (2006). How to design and evaluate research in education. New York: McGraw-Hill.

Franklin, C.A., Bargagliotti, A.E., Case, C.A., Kader, G.D., Scheaffer, R.L. \& Spangler, D.A. (2015). Statistical Education of Teachers (SET), Alexandria, VA: American Statistical Association.

Franklin, C., Kader, G., Mewborn, D., Moreno, J., Peck, R., Perry, M. et, al. (2005). Guidelines for assessment and instruction in statistics ducation (GAISE) report: A pre-K-12 curriculum framework. Alexandria, VA: American Statistical Association.

Friel, S. N., Curcio, F. R., \& Bright, G. W. (2001). Making sense of graphs: Criticalfactors influencing comprehension and instructional implications. Journal forResearch in Mathematics Education, 32, 124-158. 
Friel, S. N., Mokros, J. R., \& Russell, S. J. (1992). Used numbers. Statistics: Middles, means, and inbetweens. Dale Seymour Publications.

Gall, M. D., Gall, J. P., \& Borg, W. R. (2007). Case study research. In A. Burvikovs (Ed.), Educational research: An introduction (pp. 446-485). Boston, MA: Pearson Education.

Garfield, J.B. (2003). Assessing Statistical Reasoning. Statistics Education Research Journal, 2(1), 22-38.

Garfield, J. \& Ben-Zvi, D. (2005). A framework for teaching and assessing reasoning about variability. Statistics Education Research Journal, 4(1), 92-99.

Garfield, J.B. \& Ben-Zvi, D. (2008a). Developing students' statistical reasoning: Connecting researchand teaching practice. New York: Springer.

Garfield, J.B. \& Ben-Zvi, D. (2008b). Learning to reason about variability. In J.B. Garfield, \& D. Ben-Zvi (Eds.), Developing Students' Statistical Reasoning: Connecting Research and Teaching Practice (pp. 201-214). Springer.

Garfield, J.B. \& Ben-Zvi, D. (2008c). Learning to reason about distribution. In J.B. Garfield, \& D. BenZvi (Eds.), Developing Students' Statistical Reasoning: Connecting Research and Teaching Practice (pp. 165-186). Springer.

Garfield, J. \& Chance, B. (2000). Assessment in Statistics Education: Issues and Challenges. Mathematical Thinking and Learning, 2(1\&2), 99-125.

Garfield, J., delMas, R. \& Chance, B. (2007). Using students' informal notions of variability todevelop an understanding of formal measures of variability. In M. Lovett \& P. Shah (Eds.),Thinking with data (pp. 117-147). New York, NY: Lawrence Erlbaum.

Groth, R. E. (2007). Toward a conceptualization of statistical knowledge for teaching. Journal for Research in Mathematics Education, 38(5), 427-437.

Groth, R. E. \& Bergner, J.A. (2006). Preservice elementary teachers' conceptual and procedural knowledge of mean, median, and mode. Mathematical Thinking and Learning, 8(1),37-63.

Groth, R. E. \& Meletiou-Mavrotheris, M. (2018). Research on statistics teachers' cognitive and affective characteristics. In D. Ben-Zvi, K. Makar, \& J. Garfield (Eds.), International handbook of research in statistics education (pp. 327-355). Cham, Switzerland: Springer.

Hiebert, J. \& Lefevre, P. (1986). Conceptual and procedural knowledge in mathematics: An introductory analysis. In J. Hiebert (Eds.), Conceptual and procedural knowledge: The case of mathematics. Lawrence Erlbaum Associates, Hillsdale, 1-27.

Jacobbe, T. (2012). Elementary school teachers' understanding of mean and median. International Journal of Science and Mathematics Education, 10, 1143-1161.

Konold, C. \& Pollatsek, A. (2002). Data analysis as the search for signals in noisy processes. Journal for Research in Mathematics Education, 33(4), 259-289.

Kuntze, S. (2014). Teachers' views related to goals of the statistics classroom - from global to contentspecific. In K. Makar, B. de Sousa, \& R. Gould (Eds.), Sustainability in statistics education. Proceedings of the 9th International Conference on Teaching Statistics (ICOTS 9, July, 2014), Flagstaff, AZ, USA. Voorburg, The Netherlands: International Statistical Institute.

Leavy, A. M. (2006). Using data comparison to support a focus on distribution: Examining preservice teacher's understandings of distribution when engaged in statistical inquiry. Statistics Education Research Journal, 5(2), 89-114.

Leavy, A. M. \& O'Loughlin, N. (2006). Preservice Teachers Understanding of the Mean: Moving Beyond the Arithmetic Average. Journal of Mathematics Teacher Education, 9, 53-90.

Lee, H. S. \& Lee, J. T. (2011). Enhancing prospective teachers' coordination of center and spread: A window into teacher education material development. The Mathematics Educator, 21(1), 33-47.

Lee, C. \& Meletiou-Mavrotheris, M. (2003). Some difficulties of learning histograms in introductory statistics, Paper presented at the Joint Statistical Meeting Section on Statictical Education, 23262333.

Lincoln, Y. S., \& Guba, E. G. (1985). Naturalistic inquiry. Sage Publishing. 
Makar, K. (2004). Developing statistical inquiry: Prospective secondary mathematics and science teachers' investigations of equity and fairness through analysis of accountability data. Unpublished doctoral dissertation, University of Texas at Austin, Austin.

Makar, K. \& Confrey, J. (2003). Chunks, Clumps and Spread Out: Secondary Pre-service Teachers' Notions of Variation and Distribution. In C. Lee (Eds.), Proceedings of the Third International Research Forum on Statistical Reasoning, Thinking and Literacy (SRTL-3) (pp.). Mount Pleasant, Michigan: Central Michigan University.

Makar, K., \& Confrey, J. (2004). Secondary teachers' statistical reasoning in comparing two groups. In D. Ben-Zvi \& J. Garfield (Eds.), The challenge of developing statistical literacy, reasoning and thinking (pp. 353-374). Boston: Kluwer Academic.

Makar, K. \& Confrey, J. (2005). "Variation-talks": Articulating Meaning in Statistics. Statistics Education Research Journal, 4(1), 27-54.

Mathews, D. \& Clark, J. (2003). Successful students' conceptions of mean, standard deviation andthe central limit theorem. Unpublished paper.

Marton, F. (1988). Phenomenography: Exploring different concepts of reality. In Fetterman, D. (Ed.), Qualitative Approaches to Evaluation in Education. New York: Praeger.

Meletiou, M. \& Lee, C. (2002). Student understanding of histograms: A stumbling stone to the development of intuitions about variation. Proceedings of the Sixth International Conference on Teaching Statistics. Durban, South Africa.

Merriam, S. B. (2009). Qualitative research: A guide to design and implementation. San Fransisco: Wiley Publications.

Mickelson, W., \& Heaton, R. (2004). Primary teachers' statistical reasoning with data. In D. Ben-Zvi \& J. Garfield (Eds.), The challenge of developing statistical literacy, reasoning and thinking (pp. 327352). Dordrecht, The Netherlands: Kluwer.

Miles, M, B., \& Huberman, A. M. (1994). Qualitative data analysis: An expanded Sourcebook. Thousand Oaks, CA: Sage.

Milli Eğitim Bakanlı̆̆ı (MEB). (2009). İlköğretim Matematik Dersi 6-8. Sinıflar Öğretim Programı. Ankara, Türkiye.

Milli Eğitim Bakanlığı (MEB). (2013). Ortaokul Matematik Dersi (5,6,7, ve 8. Sintf) Öğretim Programı. Ankara, Türkiye.

Milli Eğitim Bakanlığı (MEB). (2018). Matematik Dersi Öğretim Programı (İlkokul ve Ortaokul 1, 2, 3, 4, 5, 6, 7 ve 8. Sinfflar. Ankara, Türkiye.

Moore, DS. (1990). Uncertainty. On the shoulders of giants: new approaches to numeracy. In LS Steen (Ed.), (pp. 95-137). Washington, DC: National AcademyPress.

National Council of Teachers of Mathematics [NCTM]. (2000). Principles and Standards for School Mathematics. Reston, VA: NCTM.

Pfannkuch, M. \& Reading, C. (2006). Reasoning about distribution: A complex process. Statistics Education Research Journal, 5(2), 4-9.

Pfannkuch, M.,\& Wild, C. (2004). Towards an understanding of statistical thinking. In D. Ben-Zvi \& J. Garfield (Eds.), The challenge of developing statistical literacy, reasoning, and thinking, (pp.1746). Dordrecht, the Netherlands: Kluwer Academic Publishers.

Reading, C. \& Canada, D. (2011). Teachers' Knowledge of Distribution, C. Batanero, G. Burrill, and C. Reading (Eds.), Teaching Statistics in School Mathematics-Challenges for Teaching and Teacher Education: A Joint ICMI/IASE Study, (pp. 223-234), New York.

Reading, C., \& Reid, J. (2006). An emerging hierarchy of reasoning about distribution: From a variation perspective. Statistics Education Research Journal, 5(2), 46-68.

Reading, C. \& Shaughnessy, M. (2004). Reason about variation. In D. Ben-Zvi, \& J. Garfield (Eds.), The Challenge of Developing Statistical Literacy, Reasoning, and Thinking (pp. 201-226). The Netherlands: Kluwer Academic Publishers. 
Sánchez, E.; Silva, C. B., \& Coutinho, C. (2011). Teachers' Understanding of Variation, C. Batanero, G. Burrill, and C. Reading (eds.), Teaching Statistics in School Mathematics-Challenges for Teaching and Teacher Education: A Joint ICMI/IASE Study, (pp. 211-221), New York.

Scheaffer, R. L. (2006). Statistics and mathematics: On making a happy marriage. In G. F. Burrill, \& P. C. Elliott (Eds.), Thinking and reasoning about data and chance: Sixty eighth year book (pp. 309322). Reston, VA: NCTM.

Shaughnessy, J. M. (2007). Research on statistics learning and reasoning. In F. K. Lester (Ed.), Second handbook of research on the teaching and learning of mathematics (pp. 957-1009). United States of America: Information Age Publishing.

Shulman, L., S. (1986). Those who understand: Knowledge growth in teaching. Educational Researcher, 15, 4-14.

Stein, M. K., Baxter, J. A., \& Leinhardt, G. (1990). Subject-Matter Knowledge and Elementary Instruction: A Case from Functions and Graphing. American Educational Research Journal, 27(4), 639-663.

Sorto, M. A. (2004). Prospective middle school teachers' knowledge about data analysis and its application to teaching. Unpublished doctoral dissertation, Michigan State University.

Trigwell, K. (2006). Phenomenography: An approach to research into geography education. Journal of geography in higher education, 30(2), 367-372.

Tufte, E. R. (1983). The visual display of quantitative information. Cheshire: Graphics Press.

Vermette, S. \& Savard, A. (2019). Necessary Knowledge forTeachingStatistics: Example of the Concept of Variability. In G. Burrill \& D. Ben-Zvi (Eds.), Topics and Trends in Current Statistics Education ICME-13 Monographs, (pp.225-244), Germany.

Watson, J. (2005). Developing an awareness of distribution. In K. Makar (Ed.),Reasoning about distribution: A collection of current research studies. Proceedings of the Fourth International Research Forum on Statistical Reasoning, Thinking, and Literacy, Auckland, 2-7 July 2005, Brisbane,Australia.

Watson, J. M. \& Moritz, J. B. (1999). The beginnings of statistical inference: Comparing two data sets. Educational Studies in Mathematics, 37, 145-168.

Wild, C. (2006). The Concept of Distribution. Statistics Education Research Journal, 5(2), 10-26.

Wild, C. J. \& Pfannkuch, M. (1999). Statistical thinking in empirical enquiry. International Statistical Review, 67(3), 223-265.

Yin, R. K. (2003). Applications of case study research. Beverly Hills, CA: Sage Publishing.

Zaidan, A., Z. , Ismail, Y., Yusof, M. \& Kashefi. H. (2012). "Misconceptions in Descriptive Statistics Among Postgraduates in Social Sciences." Procedia - Social and Behavioral Sciences, 46, 3535- 


\section{Extended Abstract}

\section{Introduction}

Increasing need for making data-based decisions in daily life caused statistics to become more important and made it necessary to develop individuals' knowledge and skills related to this need (Vermette \& Savard, 2019). While conducting a statistical research, one of the aims is to understand what reality means within the context (Wild, 2006). The reasoning and thinking skills play an important role in the proper execution of this process. Besides graphical representations, the concept of distribution and variability form the basis of statistical thinking and reasoning processes (Bakker, 2004). Also, the relationship between these concepts is of critical importance for the understanding of a statistical information network (Reading \& Canada, 2011). Distribution is one of the concepts present in this network (Shaughnessy, 2007). Though definition of this concept is relatively easy (Reading \& Canada, 2011), it is considered to be a concept difficult to understand (Pfannkuch \& Reading, 2006). This concept requires the simultaneous use of many concepts such as centre, distribution, variability and graphical representations (Bakker \& Gravemeijer, 2004).

Inclusion of statistical concepts and the relationships between these concepts in curriculums and putting emphasis on these concepts in the learning process have been strongly proposed (Moore, 1990). In this regard, teacher knowledge is of great importance (Ball \& McDiarmid, 1990). Research shows that having inadequate content knowledge can lead to excessive adherence to procedural operations and rules (Stein et. al.,1990). Moreover, it can be argued that lack of content knowledge negatively affects the instructional process (Borko et. al., 1992). This relationship between the content and pedagogical content knowledge makes preservice teachers' understanding of statistical concepts and knowing more about the subject they teach critical (Leavy, 2006). However, studies show that teachers/pre-service teachers have various difficulties in understanding the concept of distribution and related concepts (Bakker \& Gravemeijer, 2004). As they considered statistical measurements limited by algorithms, they evaluated the centre and variability of the distribution on the basis of various misconceptions and incorrect reasoning (Cooper \& Shore 2010). These difficulties experienced by teachers/preservice teachers show that important statistical concepts are clearly interrelated. The deficiency in a concept adversely affects the development of the other concept (Bakker, 2004). Given that the knowledge of the teacher is key for effective teaching of statistics, it can be said that having knowledge about these concepts will directly affect the learning-teaching process (Vermette \& Savard, 2019). In this context, it is thought that revealing pre-service teachers' knowledge about these concepts can provide important insights into the structuring process of related lessons. Thus, the aim of the current study is to reveal pre-service teachers' knowledge about the concept of distribution and related concepts.

\section{Method}

It was adopted phenomenographic research method. Participants were 66 third-year pre-service teachers enrolled at a state university. Interviews were conducted 40-50 minutes. While developing the interview questions, the study by Lee and Meletiou-Mavrotheris (2003) was capitalized on. Data was analyzed via descriptive analysis. 


\section{Results}

The pre-service teachers were found to be successful in naming the histogram axes in compliance with the context to a great extent. While constructing the distribution suitable for the given context, most of the pre-service teachers over-generalized some statements and overlooked the fact that standard deviation should be considered. Moreover, it was observed that the pre-service teachers were insufficient to evaluate the distribution related to real life situations. Although most of the pre-service teachers were able to make a correct connection between the graphical representation of the distribution and the variability, it was observed that they reached these connections through incorrect reasoning.

\section{Discussion}

When the knowledge and skills of the pre-service teachers about the naming of the appropriate histogram axes suitable for the given context were evaluated, two remarkable results emerged. First, although the sample given was classified as " 40 years of age and over", some of the preservice teachers evaluated the names of the selected axes according to age variable. Although the two questions asked about these knowledge and skills had the same structure, it was found that the pre-service teachers committed more mistakes in the other question. It can be thought that the pre-service teachers' confusing the histogram with the scatterplot led to such a result. The literature supports these findings (Zaidan et. al., 2012). In the process of their determining the appropriate distribution complying with the given context most of the pre-service teachers made an evaluation considering only the given values and over-generalized some statements.

The emergence of such a result can be thought to be caused by the educational experiences of the pre-service teachers (delMas \& Liu, 2005). In the literature, similar points have been emphasized (Lee \& Meletiou-Mavrotheris, 2003). Another important result emerging is that the pre-service teachers had difficulties in naming the graph appropriately as the context changed and in deciding the shape of the distribution. Similar results have been reported (Mickelson \& Heaton, 2004). It can be said that the pre-service teachers' tendency towards deterministic reasoning instead of probabilistic reasoning led to emergence of such a result (Biehler, 1994). The literature supports these findings (Makar \& Confrey, 2005). It was found that the pre-service teachers who gave the right answer in relation to the connection between the graphical representation of the distribution and the variability had various misconceptions and difficulties while reaching the answer. Some of the pre-service teachers only considered the interval. Though this statement is correct, it is not sufficient. Researchers have also emphasized that the variability of the distribution can be determined according to the interval; yet, this is not enough on its own (Vermette \& Savard, 2019). It was also observed that the pre-service teachers; despite giving the correct answer, justifying their answer through incorrect reasoning. Similar findings are accordant with this results (Cooper \& Shore 2010). When the findings were generally evaluated, it was found that although pre-service teachers' achievement levels were high, there were various deficiencies in their knowledge of statistical concepts. Thus, to overcome these challenges they should be engaged in activities helping them recognize the relationships between statistical concepts. 


\section{Ek-1}

\section{Etkinlik 1}

Bir sigorta şirketi yaşadıkları bölgede 40 yaş ve üzeri bireylerin kolestrol düzeylerini araștırmak istemektedir. Bölgedeki popülasyondan rastgele 100 kişilik bir örneklem seçilmiş ve aşağıdaki bilgiler elde edilmiştir.

Örneklem büyüklüğü: 100

Kolestrol düzeyinin medyanı: $160 \mathrm{mg}$

Ortalama kolestrol düzeyi: $158 \mathrm{mg}$

Standart sapma $20 \mathrm{mg}$

Soru 1: Yukarıdaki bilgilerden yola çıkarak 40 yaș ve üzeri bireylerin kolestrol düzeylerinin dağılım şekli ne olabilir? Nedenini açıklayınız.

Soru 2: Kolestrol düzeyleri ile ilgili histogram çizildiğinde,

Yatay eksen neyi ifade eder?

Dikey eksen neyi ifade eder?

Soru 3: Buradaki bireylerden birini kolestrol düzeyi 188 mg'dir. Sizce bu olağandişı (uç değer) bir değer midir? Neden?

\section{Etkinlik 2}

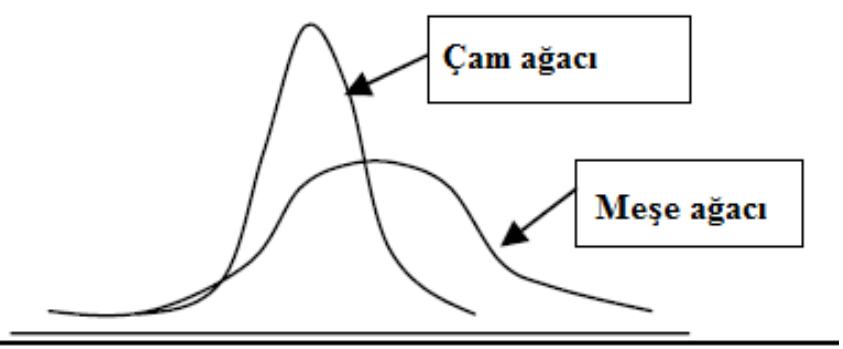

Yukarıda grafikte iki farklı ağaç türünden üretilen pencere çerçevesinin genişlikleri gösterilmiştir. Açıklamalardan hangisi doğrudur?

a)Çam ağacından üretilen pencere çerçevesinin dağılımı çarpıktır.

b)Çam ağacından üretilen pencere çerçevesinin dağılımının değişkenliği, meşe ağacından üretilen pencere çerçevesinin dağılımının değişkenliği ile benzerdir.

c)Çam ağacından üretilen pencere çerçevesinin dağılımının değişkenliği, meşe ağacından üretilen pencere çerçevesinin dağılımının değişkenliğinden büyüktür.

d)Çam ağacından üretilen pencere çerçevesinin dağılımının değişkenliği, meşe ağacından üretilen pencere çerçevesinin dağılımının değişkenliğinden küçüktür.

Lütfen seçiminizin gerekçesini açıklayınız.

\section{Etkinlik 3}

Aşağıda verilen iki dağılımdan hangisi daha fazla değişkenlik gösterir?

a) A daha fazla değişkenlik gösterir.

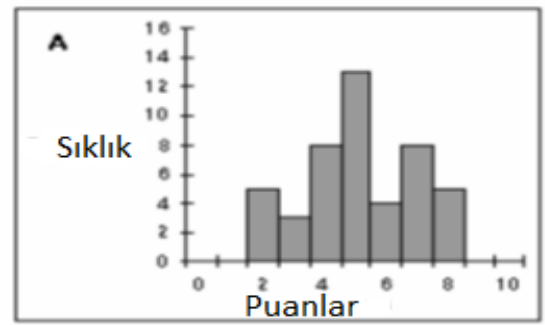

b) B daha fazla değişkenlik gösterir.

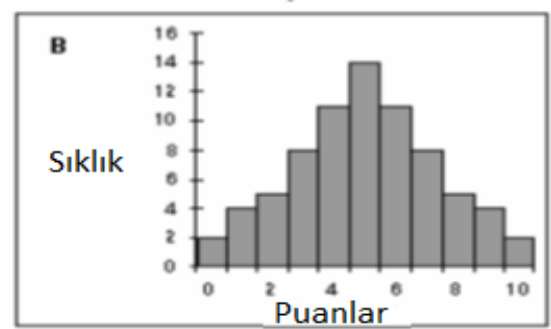

Şimdi yukarıdaki seçiminize bağlı olarak aşağıdaki seçeneklerden hangisini ya da hangilerini gerekçe olarak seçersiniz?

a)Çünkü bu seçilen dağılım daha çarpıktır.

b)Çünkü bu dağılım daha fazla geniştir. 
c)Çünkü bu dağılım daha fazla sayıda farklı puana sahiptir.

d)Çünkü bu dağılımdaki değerler merkezden daha farklı değerdedir.

e)Diğer (Lütfen açıklayınız)....

\section{Etkinlik 4}

Henüz emekli olmamış 40 yaş ve üzeri bireylerin maaşlarının dağılımı ile ilgili histogram çizildiğinde, Soru 1: Yatay eksen neyi ifade eder?

Dikey eksen neyi ifade eder?

Soru 2: Maaş dağılımının şekli neye benziyor? Neden? 